https://doi.org/10.19195/0524-4544.333.2

\author{
DOMINIKA CENDROWICZ \\ ORCID: 0000-0002-2358-7188 \\ Uniwersytet Wrocławski \\ dominika.cendrowicz@uwr.edu.pl
}

\title{
Instytucja samorządu gospodarczego w prawie polskim na tle rozwiązań krajów europejskich
}

\begin{abstract}
Abstrakt: W wyniku złożonych procesów historycznych w drugiej połowie XIX wieku w Europie Zachodniej i w Wielkiej Brytanii wykształciły się dwa modele samorządu gospodarczego: kontynentalny oraz anglosaski. W Polsce od chwili odzyskania niepodległości w 1918 roku toczył się spór o koncepcję samorządu. Obecnie obowiązujące regulacje prawne w zakresie samorządu gospodarczego nie pozwalają uznać go za część administracji publicznej w znaczeniu nauki prawa administracyjnego i odbiegają od tych obowiązujących w okresie międzywojennym. Przedmiotem publikacji jest analiza instytucji samorządu gospodarczego w prawie polskim na tle rozwiązań krajów europejskich. Publikacja odwołuje się także do rozwiązań obowiązujących w prawie polskim w międzywojniu.
\end{abstract}

Słowa kluczowe: samorząd nieterytorialny, samorząd gospodarczy, izby gospodarcze, związki publicznoprawne.

\section{Wstęp}

Pojęcie samorządu nie jest jednolicie rozumiane w nauce prawa ${ }^{1}$. W znaczeniu nauki prawa administracyjnego jest to grupa korporacyjna zrzeszająca grupy ludzi, wyodrębniona w oparciu o prawem określone kryteria ${ }^{2}$. Korpora-

${ }^{1}$ Szerzej zob. T. Bigo, Związki publiczno-prawne w świetle ustawodawstwa polskiego, Warszawa 1928, s. $51 \mathrm{n}$.

2 M. Szydło, Samorzad gospodarczy w warunkach gospodarki rynkowej, „Państwo i Prawo” 2005, z. 3, s. 94 . 
cjom samorządowym przysługuje przymiot odrębnej od państwa podmiotowości publicznoprawnej, umożliwiającej im realizację zadań publicznych w sposób samodzielny, ale z uwzględnieniem przepisów prawa powszechnie obowiązujące$\mathrm{go}^{3}$. Samorząd podlega nadzorowi państwa o zakresie określonym w ustawie 4 . Problematyka samorządu najczęściej omawiana jest w powiązaniu z tematyką samorządu terytorialnego, na którą składa się szereg istotnych kwestii prawnych ${ }^{5}$. W państwie prawa samorząd terytorialny pojmuje się jako „formę współwykonywania z administracją rządową zadań publicznych"6 oraz formę decentralizacji władzy publicznej ${ }^{7}$. Członkostwo w samorządzie terytorialnym uzależnione jest od zamieszkiwania na terenie danej jego jednostki. Powoduje to zasadniczy brak możliwości odmówienia uczestnictwa w nim, ponieważ wiodącym kryterium więzi łączących członków danej wspólnoty samorządowej jest kryterium więzi terytorialnej ${ }^{8}$.

Kryterium to nie stanowi jednak jedynego, jakie może łączyć członków danej wspólnoty samorządowej. W praktyce pojawiają się także inne, a ich występowanie umożliwia wyodrębnienie kategorii samorządu nieterytorialnego ${ }^{9}$, który w klasycznej nauce prawa administracyjnego jest tradycyjnie ujmowany w kategorii związków publicznoprawnych ${ }^{10}$. Podstawowa różnica między samorządem terytorialnym a samorządem nieterytorialnym zasadza się na tym, że w skład tego drugiego wchodzą jedynie grupy osób wyodrębnione na podstawie szczególnych kryteriów ${ }^{11}$. Wynika z tego, że samorządem są nie tylko związki lokalne o charakterze terytorialnym. Pojęcie to można odnosić również do grup osób, których członkostwo w określonym rodzaju samorządu opiera się na przykład na kryterium wykonywanego zawodu (profesji) czy więzi gospodarczych ${ }^{12}$.

3 Ibidem, s. 95.

4 J. Korczak, Konstytucyjne podstawy struktury i funkcji samorzadu terytorialnego, [w:] System Prawa Administracyjnego, t. 2. Konstytucyjne podstawy funkcjonowania administracji publicznej, red. R. Hauser, Z. Niewiadomski, A. Wróbel, Warszawa 2012, s. 243 n.

5 T. Rabska, Pozycja samorządu terytorialnego w Konstytucji, „Ruch Prawniczy, Ekonomiczny i Socjologiczny" 57, 1995, z. 2, s. 42.

${ }^{6}$ A. Błaś, Reaktywowanie samorządu terytorialnego w Rzeczypospolitej Polskiej w 1990 roku, [w:] Studia nad samorządem terytorialnym, red. A. Błaś, Wrocław 2002, s. 11.

7 T. Bigo, op. cit., s. 39 n.

${ }^{8}$ A. Gołębiowska, P. Zientarski, E. Stępień, Konstytucja Rzeczypospolitej Polskiej a samorzad terytorialny, [w:] Funkcjonowanie samorzadu terytorialnego - uwarunkowania prawne i społeczne, red. A. Gołębiowska, P. Zientarski, Warszawa 2016, s. 24.

${ }^{9}$ Określany jest również niekiedy mianem samorządu specjalnego.

10 M. Tabernacka, Samorzad nieterytorialny, [w:] Tadeusz Bigo o administracji i prawie administracyjnym — refleksje wrocławskiej szkoły administratywistycznej, red. T. Kocowski, P. Lisowski, M. Paplicki, Wrocław 2020, s. 165.

11 J. Zimmermann, Prawo administracyjne, Warszawa 2014, s. 154.

12 Z. Kmieciak, Samorzad gospodarczy w państwach Unii Europejskiej, „Roczniki Integracji Europejskiej" 2013, nr 7, s. 64. 


\section{Pojęcie i istota samorządu gospodarczego}

Do form samorządu nieterytorialnego w Polsce zalicza się w szczególności samorząd zawodowy i samorząd gospodarczy. Samorząd gospodarczy, któremu poświęcone zostaną dalsze szczegółowe rozważania, w okresie międzywojennym definiowano jako ,związek zorganizowany na zasadach przedstawicielstwa wspólnych, kolektywnych i osobistych interesów osób, należących do określonego stanu gospodarczego"13. We współczesnych warunkach ustrojowo-gospodarczych uznawany jest on za jedną z najstarszych form działania zbiorowego przedsiębiorców, której funkcjonowanie jest niezbędne dla prawidłowego rozwoju gospodarki wolnorynkowej ${ }^{14}$. Jego istnienie stanowi wyraz realizacji zasady pomocniczości. Samorząd gospodarczy powinien realizować dwojakiego rodzaju zadania: 1. wyraźnie poruczone przez państwo, w zakresie których działa w jego imieniu i współpracuje $\mathrm{z}$ administracją rządową i samorządem terytorialnym; 2. polegające na samodzielnym popieraniu i zaspokajaniu interesu danej grupy przedsiębiorców z uwzględnieniem swobody działania oraz prawa samodzielnej decyzji i prawa samostanowienia norm $\mathrm{w}$ granicach ustawowych ${ }^{15}$. Powinien również realizować zadania $\mathrm{w}$ sferze etyki biznesu i na rzecz podnoszenia kultury zachowań przedsiębiorców ${ }^{16}$. Stosownie do dziedzin można wyodrębnić samorząd gospodarczy działający w rolnictwie, przemyśle, handlu i wolnych zawodach ${ }^{17}$.

W wyniku złożonych procesów historycznych w Europie wykształciły się dwa modele samorządu gospodarczego: model kontynentalny i model anglosa$\mathrm{ski}^{18}$. W modelu kontynentalnym członkostwo w korporacji samorządowej ma obligatoryjny charakter ${ }^{19}$. W modelu anglosaskim ma ono charakter dobrowolny, co powoduje, że taki samorząd liczy zdecydowanie mniej członków niż w modelu kontynentalnym ${ }^{20}$, w którym organizacje samorządu gospodarczego posiadają przymiot korporacji prawa publicznego i władztwo administracyjne. W modelu anglosaskim stanowią one natomiast korporacje prawa prywatnego i zasadniczo nie posiadają uprawnień administracyjnych ${ }^{21}$. Model kontynentalny obowiązu-

13 J. Hubert, Samorzą gospodarczy. Skrypt z wykładów w roku akademickim 1925/1926, Poznań 1926, s. 1.

14 S. Wykrętowicz, Funkcjonowanie samorzadu gospodarczego w wybranych krajach europejskich, Warszawa 2013, s. 3.

15 R. Kmieciak, Pozycja ustrojowa samorzadu gospodarczego w Polsce, „Studia z Polityki Publicznej”" 2016, nr 2, s. 92.

16 C. Kosikowski, Wolność gospodarcza w prawie polskim, Warszawa 1995, s. 146.

17 R. Kmieciak, Pozycja..., s. 9.

18 S. Wykrętowicz, Funkcjonowanie..., s. 7. Szerzej zob. Chambers of Commerce in Europe. Self-governance and Institutional Change, red. D. Sack, Cham 2021, passim.

19 K. Bandarzewski, Samorzad gospodarczy w prawie polskim. Studium prawne, Kraków 2014, s. 284.

20 Ibidem, s. 287.

${ }^{21}$ Ibidem. 
je w krajach takich jak na przykład: Francja, Niemcy, Włochy, Hiszpania, Austria czy Słowenia ${ }^{22}$, model anglosaski zaś przyjął się między innymi w Wielkiej Brytanii, Irlandii, Finlandii, Szwecji, Czechach, Estonii, a także na Łowie i na Litwie $^{23}$. Polska uznawana jest obecnie za kraj, w którym obowiązuje anglosaski model samorządu gospodarczego, co przekłada się na charakter prawny jego organizacji i na zakres realizowanych przez nie zadań. Obecny model samorządu gospodarczego w Polsce różni się jednak zasadniczo od obowiązującego w prawie w okresie międzywojennym, co zostanie szczegółowo omówione w dalszej części publikacji.

\section{Samorząd gospodarczy w II Rzeczypospolitej}

Samorząd gospodarczy w Polsce okresu międzywojennego stanowił obok administracji rządowej i samorządu terytorialnego ważny podmiot administracji publicznej ${ }^{24}$. Po raz pierwszy jego status prawny określony został w art. 68 Konstytucji Rzeczypospolitej Polskiej z dnia 17 marca 1921 roku (dalej: Konstytucja marcowa $)^{25}$, stanowiącym, że

obok samorządu terytorialnego osobna ustawa powoła samorząd gospodarczy dla poszczególnych dziedzin życia gospodarczego, a mianowicie: Izby rolnicze, handlowe, przemysłowe, rzemieślnicze, pracy najemnej i inne, połączone w Naczelną Izbę Gospodarczą Rzeczypospolitej, których współpracę z władzami państowemi w kierowaniu życiem gospodarczym i w zakresie zamierzeń ustawodawczych określą ustawy.

Również ustawa konstytucyjna z dnia 23 kwietnia 1935 roku (dalej: Ustawa kwietniowa) ${ }^{26}$ odwoływała się instytucji samorządu gospodarczego. Przepis art. 78 Konstytucji kwietniowej stanowił, że „Dla poszczególnych dziedzin życia gospodarczego powołuje się samorząd gospodarczy, obejmujący izby rolnicze, przemysłowo-handlowe, rzemieślnicze, pracy, wolnych zawodów oraz inne zrzeszenia publiczno-prawne”. W dalszej części tego przepisu mowa była o tym, iż „,[u]stawy mogą łączyć izby w związki i nadawać im osobowość publiczno-

22 Podaję za: International Chamber of Commerce, History of the Chamber Movement, https:// iccwbo.org/chamber-services/world-chambers-federation/history-chamber-movement/ (dostęp: 6.02. 2021). Zob. R.G. Vambery, P. Mayer, From Government Focus to Customer Focus: The Challenge Facing Chamber of Commerce in Central and Eastern Europe, „Journal of Global Business and Technology" 1, 2005, nr 2, s. 51-64.

23 R. Kmieciak, Samorzad gospodarczy..., s. 65.

24 S. Wykrętowicz, Powstanie i rozwój samorządu gospodarczego w Europie i w Polsce, [w:] Spór o samorząd gospodarczy, red. S. Wykrętowicz, Poznań 2005, s. 16. Szerzej zob. K. Dąbrowski, Samorzad gospodarczy w okresie II RP w pogladach J. Huberta, W.L. Jaworskiego, W. Wakara i W.Szcz. Wachholtza, „Administracja. Teoria - Dydaktyka — Praktyka” 2009, nr 3 (16), s. 116-139.

${ }^{25}$ Konstytucja Rzeczypospolitej Polskiej z dnia 17 marca 1921 roku (Dz.U. Nr 44, poz. 267).

26 Ustawa konstytucyjna z dnia 23 kwietnia 1935 roku (Dz.U. Nr 30, poz. 227). 
-prawną". Zarówno Konstytucja marcowa, jak i Konstytucja kwietniowa wykreowały podmiot w postaci Naczelnej Izby Gospodarczej. Po raz pierwszy informacja o Izbie pojawiła się w art. 68 Konstytucji marcowej i chociaż nie została ona powołana przez cały okres obowiązywania ustawy, to w art. 76 Konstytucji kwietniowej ją utrzymano ${ }^{27}$.

Poza aktami prawnymi rangi konstytucyjnej do działalności samorządu gospodarczego w prawie polskim okresu międzywojennego odwoływały się przepisy rozporządzeń: Prezydenta Rzeczypospolitej z dnia 7 czerwca 1927 roku o prawie przemysłowym $^{28}$; Ministra Przemysłu i Handlu z dnia 12 grudnia 1927 roku o ustanowieniu izb rzemieślniczych, wyznaczeniu ich siedzib i okręgów ${ }^{29}$; Prezydenta Rzeczypospolitej z dnia z 27 października 1933 roku o izbach rzemieślniczych i ich związku ${ }^{30}$; Prezydenta Rzeczypospolitej z dnia 15 lipca 1927 roku o izbach przemysłowo-handlowych ${ }^{31}$; oraz Prezydenta Rzeczypospolitej z dnia 22 marca 1928 roku o izbach rolniczych ${ }^{32}$. Definicja legalna samorządu gospodarczego znajdowała się w $\S 40$ ustęp 3 rozporządzenia Rady Ministrów z dnia 28 maja 1934 roku w sprawie wykonania ustawy z dnia 11 grudnia 1923 roku o zaopatrzeniu emerytalnem funkcjonarjuszów państwowych i zawodowych wojskowych ${ }^{33}$, zgodnie z którym

przez instytucje, przedsiębiorstwa i zakłady samorządu gospodarczego, rozumieć [...] [należało D.C.] specjalne organy, oparte na zasadzie wybieralności, wyposażone w pewną samodzielność, funkcjonujące pod nadzorem władz państwowych i powołane do współdziałania z tymi władzami w kierowaniu życiem gospodarczym (izby rolnicze, przemysłowe, handlowe, rzemieślnicze, pracy najemnej itd.).

Mocą tego przepisu wyraźnie odróżniono instytucję samorządu gospodarczego od samorządu zawodowego. Ten drugi tworzyły izby adwokackie, lekarskie, aptekarskie, samorządu oświatowego i wyznaniowego ${ }^{34}$.

27 A. Szustek, Naczelna Izba Gospodarcza, Warszawa 2017, s. 13.

28 Rozporządzenie Prezydenta Rzeczypospolitej z dnia 7 czerwca 1927 roku o prawie przemysłowym (Dz.U. Nr 53, poz. 468).

29 Rozporządzenie Ministra Przemysłu i Handlu z dnia 12 grudnia 1927 roku o ustanowieniu izb rzemieślniczych, wyznaczeniu ich siedzib i okręgów (Dz.U. Nr 117, poz. 1003).

30 Rozporządzenie Prezydenta Rzeczypospolitej z dnia 27 października 1933 roku o izbach rzemieślniczych i ich związku (Dz.U. Nr 85, poz. 638).

31 Rozporządzenie Prezydenta Rzeczypospolitej z dnia 15 lipca 1927 roku o izbach przemysłowo-handlowych (Dz.U. Nr 67, poz. 591).

32 Rozporządzenie Prezydenta Rzeczypospolitej z dnia 22 marca 1928 roku o izbach rolniczych (Dz.U. Nr 39, poz. 385).

33 Rozporządzenie Rady Ministrów z dnia 28 maja 1934 roku w sprawie wykonania ustawy z dnia 11 grudnia 1923 roku o zaopatrzeniu emerytalnem funkcjonarjuszów państwowych i zawodowych wojskowych (Dz.U. Nr 60, poz. 513).

34 K. Dąbrowski, Izby przemystowo-handlowe Drugiej Rzeczypospolitej jako instytucje samorządu przemystowo-handlowego. Ujęcie doktrynalne i konstytucyjne, „Studia z Dziejów Państwa i Prawa Polskiego" 2007, nr 10, s. 307. 
Tadeusz Bigo, odwołując się do koncepcji związków publicznoprawnych na tle przepisów Konstytucji marcowej, przypisywał samorządowi gospodarczemu przymiot korporacji prawa publicznego i zwracał uwagę na kwestię przymusowej przynależności do niego ${ }^{35}$. Analizując pozycję izb przemysłowo-handlowych, wprost określał je mianem „osoby publicznoprawnej”36, a także twierdził, że poza samorządem terytorialnym i samorządem gospodarczym istnieje wiele innych związków publicznoprawnych, stąd nie może on ograniczać się tylko do tych dwóch rodzajów samorządu ${ }^{37}$. Tematyka samorządu gospodarczego obecna była również w pracach Jerzego Panejki, który — podobnie jak Bigo — przypisywał mu charakter związku publicznoprawnego ${ }^{38}$. Z kolei Marian Kannenberg uważał, że w art. 68 Konstytucji marcowej nie określono, jaki ma być ustrój samorządu gospodarczego, poza tym, że będzie on dwustopniowy. Kwestia oddzielnych organizacji samorządowych poszczególnych działów gospodarki lub branż pozostawała jego zdaniem otwarta. Izby, które zostały wymienione w art. 68 Konstytucji marcowej, uznawał za jedynie przykładowe, a także twierdził, że „warstwy zawodowe" będą organizowały się w izby. Jako przykład wymieniał izby samorządu gospodarczego (handlowe, rolnicze), a także samorządu zawodowego (adwokackie, lekarskie) $^{39}$. Pod rządami Konstytucji kwietniowej instytucję samorządu gospodarczego analizował Jerzy Stefan Langrod, który zwracał uwagę, że obejmuje on nie tylko korporacje samorządu zawodowego, ale także inne związki publicznoprawne ${ }^{40}$.

Podczas przywoływania powyższych poglądów warto zwrócić uwagę, że we współczesnej nauce prawa spotkać można opinię, zgodnie z którą w okresie międzywojennym

stworzono równolegle podstawy prawne do działania samorządu gospodarczego jako instytucji prawa prywatnego (rozporządzenie Prezydenta RP z dnia 7 czerwca 1927 r. o prawie przemysłowym [...]) oraz jako instytucji prawa publicznego (rozporządzenie Prezydenta RP z dnia 15 lipca 1927 r. o izbach przemysłowo-handlowych $[\ldots])^{41}$.

Przeważa jednak zdanie, że w II Rzeczypospolitej organizacje samorządu gospodarczego były podmiotami prawa publicznego ${ }^{42}$. Wypracowane w międzywojniu rozwiązania bazowały na tych przyjętych w Niemczech i we Francji, a samorząd gospodarczy na gruncie przepisów zarówno Konstytucji marcowej, jak i Konstytucji kwietniowej stanowił aktywnego partnera administracji rządowej

35 T. Bigo, op. cit., s. 74.

36 Ibidem, s. 64.

37 Ibidem, s. 186.

38 J. Panejko, Geneza i podstawy samorzadu europejskiego, Paryż 1926, s. 111.

39 M. Kannenberg, Naczelna Izba Gospodarcza. Referat wygtoszony w Towarzystwie Ekonomicznym w Krakowie w dniu 1 kwietnia 1922 r., Kraków 1922. Podaję za: A. Szustek, op. cit., s. 302.

40 J.S. Langrod, Problemy administracyjne w konstytucji, Kraków 1936, s. 13 n.

41 C. Kosikowski, Prawo działalności gospodarczej. Komentarz, LEX/el. 2002.

${ }^{42}$ K. Bandarzewski, op. cit., s. 65. 
i samorządu terytorialnego $\mathrm{w}$ zakresie zarządzania sprawami funkcjonowania gospodarki. Osiągnięcia okresu międzywojennego w tej dziedzinie zostały jednak zaprzepaszczone po 1945 roku, kiedy trudno było mówić o jakichkolwiek jego formach $^{43}$. Konstytucja Polskiej Rzeczypospolitej Ludowej z dnia 22 lipca 1952 ro$\mathrm{ku}^{44}$ nie zawierała żadnej wzmianki o samorządzie gospodarczym, a jedynie w jej art. 12 była mowa, iż „Polska Rzeczpospolita Ludowa uznaje i ochrania na podstawie obowiązujących ustaw indywidualną własność i prawo dziedziczenia ziemi, budynków i innych środków produkcji należących do chłopów, rzemieślników i chałupników." W analizowanym okresie funkcjonowały izby rzemieślnicze na podstawie ustawy z dnia 8 czerwca 1972 roku o wykonywaniu i organizacji rzemiosła $^{45}$, które zgodnie z jej art. 31 ust. 1 stanowiły „społeczno-zawodowe i gospodarcze organizacje rzemiosła".

\section{Samorząd gospodarczy w prawie polskim po 1989 roku}

Obecnie w prawie krajowym do instytucji samorządu gospodarczego odwołuje się art. 17 ust. 2 Konstytucji Rzeczypospolitej Polskiej z dnia 2 kwietnia 1997 roku (dalej: Konstytucja RP) ${ }^{46}$. Przepis ten stanowi o możliwości tworzenia w drodze ustawy innych form samorządu niż samorząd terytorialny. Jest w nim również informacja, że inne formy samorządu, o których w nim mowa, nie mogą naruszać wolności wykonywania zawodu ani ograniczać wolności podejmowania działalności gospodarczej ${ }^{47}$. Omawiany przepis nie stanowi wprost, o jakie inne rodzaje samorządu w nim chodzi. Marek Szydło wskazuje jednak, że mowa tutaj przede wszystkim o samorządzie gospodarczym, ale również o samorządzie niegospodarczym. Jego zdaniem za przyjęciem takiego stanowiska przesądza to, że zgodnie z omawianym przepisem inne rodzaje samorządów, o których w nim mowa, nie powinny naruszać wolności wykonywania zawodu ani ograniczać wolności podejmowania działalności gospodarczej. Przemawia za tym również

43 M. Błachucki, Przemiany ustrojowe samorzadu specjalnego w polskim prawie administracyjnym, [w:] Prace Studialne Warszawskiego Seminarium Aksjologii Administracji. Szkice z zakresu procedury administracyjnej, t. 3, red. K. Wąsowski, K. Zalasińska, Kraków 2014, s. 17. Szerzej zob. J. Basta, Proces likwidacji samorządu gospodarczego w Polsce (1945-1949), „Studia Historyczne” 40, 1997, nr 4, s. 561-571.

44 Konstytucja Polskiej Rzeczypospolitej Ludowej uchwalona przez Sejm Ustawodawczy w dniu 22 lipca 1952 roku (Dz.U. Nr 33, poz. 232).

45 Ustawa z dnia 8 czerwca 1972 roku o wykonywaniu i organizacji rzemiosła (Dz.U. Nr 23, poz. 164).

46 Konstytucja Rzeczypospolitej Polskiej z dnia 2 kwietnia 1997 roku (Dz.U. Nr 78, poz. 483 ze zm.).

47 M. Błachucki, op. cit., s. 20. 
wykładnia historyczna nawiązująca do analogicznych przepisów Konstytucji marcowej i kwietniowej oraz odwołanie się do prac Komisji Konstytucyjnej Zgromadzenia Narodowego ${ }^{48}$.

Pojęcie samorządu gospodarczego pojawia się w art. 61 Konstytucji RP w kontekście prawa obywateli do uzyskiwania informacji o działalności organów władzy publicznej oraz osób pełniących funkcje publiczne ${ }^{49}$. Analizując w dalszej kolejności pojęcie samorządu gospodarczego na tle przepisów Konstytucji RP, musimy zauważyć, że dotyczy ono „organizacji zrzeszających (grupujących) osoby podejmujące lub wykonujące działalność gospodarczą" ${ }^{50}$. Wynika stąd, że dla pełnego wyjaśnienia tego pojęcia ważne jest odwołanie się do art. 3 ustawy z dnia 6 marca 2018 roku - Prawo przedsiębiorców ${ }^{51}$, zawierającego definicję działalności gospodarczej, którą zgodnie z jego brzmieniem jest zorganizowana działalność zarobkowa, wykonywana we własnym imieniu i w sposób ciągły ${ }^{52}$.

Do organizacji samorządu gospodarczego w Polsce należą izby gospodarcze, organizacje zawodowe samorządu przedsiębiorców, organizacje pracodawców i organizacje samorządu gospodarczego rzemiosła. Działalność samorządu gospodarczego regulowana jest ustawami: z dnia 30 maja 1989 roku o izbach gospodarczych ${ }^{53}$, z dnia 30 maja 1989 roku o samorządzie zawodowym niektórych podmiotów gospodarczych ${ }^{54}$, z dnia 22 marca 1989 roku o rzemiośle (dalej: u.o.r. $)^{55}$ oraz z dnia 14 grudnia 1995 roku o izbach rolniczych ${ }^{56}$. Ustawy te określają zadania i organizacje samorządu gospodarczego oraz tryb ich powoływania i sposoby finansowania ${ }^{57}$.

Izby gospodarcze z punktu widzenia nauki prawa administracyjnego nie są instytucjami prawa publicznego ${ }^{58}$. Zgodnie z art. 1 ustawy z dnia 30 maja 1989 roku. o samorządzie zawodowym niektórych podmiotów gospodarczych (dalej: u.i.g.) przedsiębiorcy mogą zrzeszać się w izby gospodarcze działające na podstawie

48 M. Szydło, Komentarz do art. 17, [w:] Konstytucja RP. T. 1, Komentarz, red. M. Safjan, L. Bosek, Warszawa 2016, s. 456.

49 Ibidem, s. 456.

50 Ibidem.

51 Ustawa z dnia 6 marca 2018 roku - Prawo przedsiębiorców (Dz.U. z 2021 r. poz. 162).

52 M. Szydło, Komentarz do art 17..., s. 456. Na temat pojęcia działalności gospodarczej zob. wyrok Trybunału Konstytucyjnego z dnia 7 maja 2001 roku, sygn. K 19/00, OTK ZU 2001, nr 4, poz. 82 oraz wyrok Trybunału Konstytucyjnego z dnia 19 stycznia 2010 roku, sygn. SK 35/08, OTK ZU 2010, seria A, nr 1, poz. 2.

53 Ustawa z dnia 30 maja 1989 roku o izbach gospodarczych (Dz.U. z 2019 r. poz. 579).

54 Ustawa z dnia 30 maja 1989 roku o samorządzie zawodowym niektórych podmiotów gospodarczych (Dz.U. Nr 35, poz. 194 ze zm.).

55 Ustawa z dnia 22 marca 1989 roku o rzemiośle (Dz.U. z 2020 r. poz. 2159).

56 Ustawa z dnia 14 grudnia 1995 roku o izbach rolniczych (Dz.U. z 2018 r. poz. 1027).

57 K. Walkowiak, Samorzad gospodarczy jako partner samorzadu terytorialnego w rozwoju gospodarki lokalnej i regionalnej, „Problemy Zarządzania, Finansów i Marketingu” 2014, nr 35, s. 99.

58 Ibidem, s. 100. 
przepisów u.i.g. i statutów. Założyciele izby gospodarczej, w celu jej utworzenia, uchwalają jej statut, potwierdzając jego przyjęcie przez złożenie swoich podpisów. Statut izby nie może ograniczać uprawnień przedsiębiorców do zrzeszania się w izbie gospodarczej (art. 7 ust. 2 i 3 u.i.g.). Do przykładowych zadań izb gospodarczych należy: reprezentacja interesów gospodarczych zrzeszonych w izbie przedsiębiorców, w szczególności wobec organów władzy publicznej (art. 2 u.i.g.); kształtowanie i upowszechnianie zasad etyki w działalności gospodarczej, w szczególności opracowywanie i doskonalenie norm rzetelnego postępowania w obrocie gospodarczym (art. 3 u.i.g.); przyczynianie się do tworzenia warunków rozwoju życia gospodarczego oraz wspieranie inicjatyw gospodarczych zrzeszonych w izbach członków (art. 5 ust. 2 pkt 1 u.i.g.). Izby są uprawnione do wyrażania opinii o projektach rozwiązań odnoszących się do funkcjonowania gospodarki oraz mogą uczestniczyć, na zasadach określonych w odrębnych przepisach, w przygotowywaniu projektów aktów prawnych w tym zakresie. Nadzór nad izbami gospodarczymi sprawuje wojewoda (art. 4 ust. 1 u.i.g.). Izby gospodarcze mogą na zasadzie dobrowolności zrzeszać się w Krajowej Izbie Gospodarczej, która reprezentuje wspólne interesy zrzeszonych w niej członków. W Krajowej Izbie Gospodarczej mogą zrzeszać się również organizacje gospodarcze i społeczne, których przedmiotem działania jest wspieranie rozwoju gospodarczego (art. 11 ust. 1-3 u.i.g.).

Kolejną z organizacji samorządu gospodarczego w Polsce jest samorząd rzemiosła, który skupia osoby posiadające status rzemieślnika w rozumieniu art. 2 ust. 1 u.o.r. Rzemieślnikiem jest każdy, kto zawodowo wykonuje działalność gospodarczą z udziałem kwalifikowanej pracy własnej, we własnym imieniu i na własny rachunek, przy zatrudnieniu poniżej 50 pracowników. Wyłączeniu z zakresu pojęcia rzemiosła podlega działalność handlowa, usługi hotelarskie, działalność transportowa, usługi świadczone w wykonywaniu wolnych zawodów, usługi lecznicze oraz działalność wytwórcza i usługowa artystów plastyków i fotografików (art. 2 ust. 4 u.o.r.). Kwestia określenia, kto jest rzemieślnikiem w rozumieniu u.o.r., pozostaje niezależna od przystąpienia do organizacji samorządu rzemiosła $^{59}$. Jako przykład organizacji samorządu rzemiosła można wskazać cechy, które powstają z inicjatywy założycieli i mają charakter dobrowolny. Wskazać przy tym należy, że z przynależnością do organizacji samorządu rzemiosła łączą się określone prawa i obowiązki. Do zadań cechu należy w szczególności: utrwalanie więzi środowiskowych oraz postaw zgodnych z zasadami etyki i godności zawodu; prowadzenie na rzecz członków działalności społecznej, organizacyjnej, kulturalnej, oświatowej i gospodarczej; także reprezentowanie interesów zrzeszonych rzemieślników. Samorząd gospodarczy rzemiosła jest niezależny w wykonywaniu swoich zadań i w tym zakresie podlega przepisom prawa (art. 7 ust. 2 u.o.r.). Izby rzemieślnicze zrzeszające cechy i spółdzielnie rzemieślnicze mają

59 Wyrok Naczelnego Sądu Administracyjnego z dnia 14 marca 2006 roku, sygn. I OSK 1344/05, LEX nr 198287. 
charakter prywatnoprawny ${ }^{60}$. Mogą one wykonywać zadania zlecone z zakresu administracji rządowej, przekazane ustawami lub na podstawie porozumień z właściwymi organami administracji rządowej. Zadania te są realizowane po zapewnieniu im koniecznych środków finansowych przez administrację rządową lub samorząd terytorialny.

Z powyższych rozważań wynika, że przynależność do samorządu gospodarczego w Polsce nie jest obowiązkowa, przy czym wyjątek stanowi ubezpieczeniowy samorząd gospodarczy ${ }^{61}$. Samorząd gospodarczy nie posiada kompetencji do wykonywania czynności o charakterze władczym, za pośrednictwem których mógłby wpływać na ograniczanie swobody działalności gospodarczej przedsiębiorców $^{62}$, nie realizuje zadań zleconych administracji gospodarczej ani nie jest podmiotem prawa publicznego. Należy jednak wspomnieć, że uznanie go za instytucję prawa publicznego przewidywał poselski projekt ustawy o izbach przemysłowo-handlowych z dnia 15 września 1995 roku $^{63}$.

\section{Rozwiązania prawne w zakresie samorządu gospodarczego w wybranych krajach europejskich}

Próbując odpowiedzieć na pytanie o przyjęty model funkcjonowania samorządu gospodarczego w prawie polskim, warto odwołać się do rozwiązań prawnych krajów Europy Zachodniej, w tym także Wielkiej Brytanii, gdzie organizacje samorządu gospodarczego są od lat ważnym reprezentantem interesów gospodarczych przedsiębiorców ${ }^{64}$. Jako pierwsze omówione zostaną rozwiązania prawne przyjęte w Niemczech i we Francji, gdzie funkcjonuje model kontynentalny samorządu gospodarczego. W Niemczech, podobnie jak w Polsce, samorząd gospodarczy jest odróżniany od samorządu zawodowego. Na samorząd gospodarczy składają się tutaj izby przemysłowo-handlowe, izby rolnicze i izby rzemieślnicze, z których te pierwsze działają na podstawie ustawy z dnia 18 grudnia 1956 ro$\mathrm{ku}$, tak zwanej Bundesgesetz ${ }^{65}$. Ustawa reguluje jednolite ramy organizacyjne izb przy równoczesnym dopuszczeniu ich rozszerzenia o specyfikę gospodarczą

${ }^{60}$ K. Walkowiak, op. cit., s. 99.

61 Obligatoryjnie tworzy się jednak Polską Izbę Ubezpieczeń Społecznych, dla której podstawą prawną działania jest ustawa z dnia11 września 2015 roku o działalności ubezpieczeniowej (Dz.U. z 2020 r. poz. 895 ze zm.).

62 M. Szydło, Samorzą..., s. 96.

63 C. Kosikowski, Prawo działalności...

${ }^{64}$ R. Kmieciak, P. Antkowiak, K. Walkowiak, Samorzad zawodowy i gospodarczy w systemie politycznym Polski, Warszawa 2012, s. 113.

65 Gesetz zur vorlaufigen Regelung des Rechts der Industrie- und Handelskammern, BGBI I 1956, 920. 
landów, a niekiedy również w oparciu o ich historyczne uwarunkowania. Funkcjonujący w Niemczech system izb przemysłowo-handlowych jest dwuszczeblowy, a izby gospodarcze uznaje się za korporacje prawa publicznego, w których członkostwo jest obligatoryjne. Niemieckie izby gospodarcze posiadają również władztwo administracyjne ${ }^{66}$, ,[są] zatem instytucjami samorządu gospodarczego w znaczeniu teorii prawa administracyjnego"67. Do ich najważniejszych zadań zalicza się: prowadzenie rejestru członków izby; opracowywanie różnego rodzaju opinii i ekspertyz; orzekanie w sprawach gospodarczych na podstawie konsultacji ekspertów; prowadzenie doradztwa na rzecz przedsiębiorców; szkolnictwo zawodowe oraz realizacja czynności administracyjnych związanych z udzielaniem koncesji na prowadzenie przedsiębiorstw. Za szczególnie ważne zadania izb w Niemczech uznaje się te związane z działalnością oświatową ${ }^{68}$. We Francji samorząd gospodarczy tworzą natomiast izby przemysłowo-handlowe oparte na trójstopniowym podziale ${ }^{69}$. Wśród ich ważniejszych zadań należy wymienić: przekazywanie instytucjom rządowym opinii i informacji na temat problematyki przemysłu i handlu; działalność edukacyjno-szkoleniowa; udzielanie informacji gospodarczej, technicznej; a także działalność wydawniczo-promocyjna ${ }^{70}$. Izby konsultują projekty aktów prawnych dotyczących gospodarki ${ }^{71}$ i zarządzają częścią morskich portów handlowych i rzecznych, a także portami morskimi, rybackimi, targami rybnymi, portami turystycznymi, portami pasażerskimi i częścią francuskich lotnisk ${ }^{72}$. Francuskie izby przemysłowo-handlowe posiadają ustrój korporacji prawa publicznego oraz są podmiotami zdecentralizowanej administracji państwowej ${ }^{73}$.

$\mathrm{W}$ grupie krajów z anglosaskim modelem samorządu gospodarczego jako pierwszy omówiony zostanie przykład Wielkiej Brytanii, w której nie ma jednolitych rozwiązań w zakresie jego funkcjonowania. W kraju tym izby gospodarcze są zakładane jako spółki z ograniczoną odpowiedzialności lub jako stowarzyszenia. Zasadniczo istnieją tutaj dwa szczeble izb gospodarczych, a do ich podstawowych zadań należy: wspieranie i reprezentowanie interesów przedsiębiorców; przeprowadzanie analiz rynku pracy; działalność informacyjna, szkoleniowa i wydawnicza; promocja eksportu; a także opiniowanie projektów aktów prawnych ${ }^{74}$. Reprezentacją krajową omawianych izb jest Zrzeszenie Brytyjskich Izb Handlo-

66 R. Kmieciak, Samorząd gospodarczy..., s. 70.

67 Ibidem.

${ }^{68}$ K. Bandarzewski, op. cit., s. 280-281.

69 Zob. S. Waters, Chambers of Commerce and Local Development in France: Problems and Constraints, „Environment and Planning C: Government and Policy” 16, 1998, z. 5, s. 591-604.

${ }^{70}$ K. Bandarzewski, op. cit., s. 282.

71 Ibidem, s. 283.

72 R. Kmieciak, Samorzad gospodarczy..., s. 68.

73 Ibidem, s. 65.

${ }^{74}$ K. Bandarzewski, op. cit., s. 285-286. 
wych (The British Chambers of Commerce - BCC ${ }^{75}$, na którego rzecz zespolone izby handlowe uiszczają opłatę stowarzyszeniową. Egzemplifikacją tego systemu jest ustrój prawny polskich izb gospodarczych ${ }^{76}$. Kolejnym krajem, w którym funkcjonuje model anglosaski, jest Irlandia, gdzie izby przemysłowo-handlowe zakładane są na podstawie prawa prywatnego ${ }^{77}$. Model anglosaski przyjął się także w krajach skandynawskich. Jako przykład można wskazać Szwecję, gdzie funkcjonują izby przemysłowo-handlowe, które wśród zadań mają: tworzenie warunków sprzyjających rozwojowi handlu i przemysłu, działalność informacyjną, arbitraż, realizację określonych zadań na zlecenie administracji rządowej i wywieranie wpływu na kształt ustawodawstwa w zakresie funkcjonowania gospodarki ${ }^{78}$. Z analizy zadan, jakie realizują organizacje samorządu gospodarczego w krajach, w których przyjęty został model anglosaski, wynika, że model ten jest zbieżny z katalogiem zadań przypisanych do realizacji organizacjom samorządu gospodarczego w Polsce.

\section{Konkluzja}

Reasumując, należy stwierdzić, że obecnie obowiązujące w prawie polskim uregulowania w zakresie samorządu gospodarczego nie zapewniają izbom pozycji związków publicznoprawnych, jak ma to miejsce na przykład w Niemczech czy we Francji ${ }^{79}$. Organizacje samorządu gospodarczego w Polsce opierają się na fakultatywnym członkostwie i w tym zakresie przyjęty w prawie polskim model samorządu gospodarczego jest zbliżony do obowiązującego w Wielkiej Brytanii. Jedynie ustawa o izbach rolniczych w art. 1 stanowi, że rolnicy mają obligatoryjny samorząd rolników. Zwraca się jednak uwagę, że społeczno-zawodowe organizacje rolników nie zostały określone przez ustawodawcę mianem samorządu rolniczego i nie posiadają cech pozwalających na uznanie ich za kategorię organizacji samorządowych ${ }^{80}$. W literaturze podkreśla się, że fakultatywne członkostwo w organizacjach samorządu gospodarczego przekłada się na liczbę jego członków, a także ogranicza ich stabilność finansową ${ }^{81}$. Przywrócenie w Polsce

75 The British Chamber of Commerce, https://www.britishchambers.org.uk/ (dostęp: 9.02. 2021).

76 M. Jurewicz, Brytyjski model systemu prawnego izb handlowych o dobrowolnym udziale przedsiębiorców, „Ekonomiczne Problemy Usług” 2012, nr 97, s. 383.

77 P. Świderski, Wpływ organizacji samorząu gospodarczego na rozwój regionów w krajach zachodnich Unii Europejskiej, „Państwo i Społeczeństwo” 2004, nr 4, s. 54.

${ }^{78}$ K. Bandarzewski, op. cit., s. 286-287.

79 R. Kmieciak, Pozycja ustrojowa..., s. 89.

${ }^{80}$ K. Bandarzewski, op. cit., s. 14.

81 Ibidem, s. 12. 
samorządu gospodarczego w znaczeniu nauki prawa administracyjnego to postulat wynikający stąd, że obowiązujące uregulowania Konstytucji RP dotyczące tej problematyki nie pozwalają na uznanie samorządu gospodarczego za część administracji publicznej ${ }^{82}$, przez co niekiedy zarzuca się mu nieskuteczność w zakresie „zbiorowego działania przedsiębiorców na rzecz ładu rynkowego" 83 . Równolegle należy pamiętać, że ewentualne wprowadzenie obligatoryjnego samorządu gospodarczego powinny poprzedzić nie tylko szczegółowa analiza zadań, jakie miałby on realizować ${ }^{84}$, ale także uwzględnienie oczekiwań przedsiębiorców, co do jego kształtu ${ }^{85}$. Niedoskonałości regulacji prawnej w zakresie samorządu gospodarczego w początkowym okresie po 1989 roku skłoniły do podjęcia działań mających na celu uchwalenie jednolitej ustawy o samorządzie gospodarczym ${ }^{86}$. Do chwili obecnej ustawa ta nie została jednak uchwalona. Nie wydaje się również, aby tego rodzaju akt prawny został przyjęty w najbliższym czasie.

\section{Bibliografia}

Bandarzewski K., Samorzą gospodarczy w prawie polskim. Studium prawne, Kraków 2014.

Basta J., Proces likwidacji samorzadu gospodarczego w Polsce (1945-1949), „Studia Historyczne” 40, 1997, nr 4.

Bigo T., Związi publiczno-prawne w świetle ustawodawstwa polskiego, Warszawa 1928.

Błachucki M., Przemiany ustrojowe samorzadu specjalnego w polskim prawie administracyjnym, [w:] Prace Studialne Warszawskiego Seminarium Aksjologii Administracji. Szkice z zakresu procedury administracyjnej, t. 3, red. K. Wąsowski, K. Zalasińska, Kraków 2014.

Błaś A., Reaktywowanie samorządu terytorialnego w Rzeczypospolitej Polskiej w 1990 roku, [w:] Studia nad samorządem terytorialnym, red. A. Błaś, Wrocław 2002.

Dąbrowski K., Izby przemystowo-handlowe Drugiej Rzeczypospolitej jako instytucje samorzadu przemystowo-handlowego. Ujęcie doktrynalne i konstytucyjne, „Studia z Dziejów Państwa i Prawa Polskiego" 2007, nr 10.

Dąbrowski K., Samorzad gospodarczy w okresie II RP w pogladach J. Huberta, W.L. Jaworskiego, W. Wakara i W.Szcz. Wachholtza, „Administracja. Teoria - Dydaktyka - Praktyka” 2009, nr 3 (16).

Gola J., Horubski K., Funkcjonowanie izb gospodarczych jako przejaw samorządności przedsiębiorców, [w:] Prawna działalność instytucji społeczeństwa obywatelskiego, red. J. Blicharz, J. Boć, Wrocław 2009.

82 Ibidem, s. 115.

83 S. Wykrętowicz, Powstanie i rozwój..., s. 19.

${ }^{84}$ K. Bandarzewski, op. cit., s. 289.

${ }^{85}$ K. Horubski, J. Gola, Funkcjonowanie izb gospodarczych jako przejaw samorzadności przedsiębiorców, [w:] Prawna działalność instytucji społeczeństwa obywatelskiego, red. J. Blicharz, J. Boć, Wrocław 2009, s. 285.

${ }^{86}$ R. Kmieciak, Pozycja ustrojowa..., s. 97. 
Gołębiowska A., Zientarski P., Stępień E., Konstytucja Rzeczypospolitej Polskiej a samorząd terytorialny, [w:] Funkcjonowanie samorzadu terytorialnego - uwarunkowania prawne i społeczne, red. A. Gołębiowska, P. Zientarski, Warszawa 2016.

Hubert J., Samorzą gospodarczy. Skrypt z wyktadów w roku akademickim 1925/1926, Poznań 1926.

Jurewicz M., Brytyjski model systemu prawnego izb handlowych o dobrowolnym udziale przedsiębiorców, „Ekonomiczne Problemy Usług” 2012, nr 97.

Kmieciak R., Antkowiak P., Walkowiak K., Samorzad zawodowy i gospodarczy w systemie politycznym Polski, Warszawa 2012.

Kmieciak R., Pozycja ustrojowa samorzadu gospodarczego w Polsce, „Studia z Polityki Publicznej” 2016, nr 2.

Kmieciak Z., Samorzą gospodarczy w państwach Unii Europejskiej, „Roczniki Integracji Europejskiej" 2013, nr 7.

Korczak J., Konstytucyjne podstawy struktury i funkcji samorządu terytorialnego, [w:] System Prawa Administracyjnego, t. 2. Konstytucyjne podstawy funkcjonowania administracji publicznej, red. R. Hauser, Z. Niewiadomski, A. Wróbel, Warszawa 2012.

Kosikowski C., Prawo działalności gospodarczej. Komentarz, LEX/el. 2002.

Kosikowski C., Wolność gospodarcza w prawie polskim, Warszawa 1995.

Langrod J.S., Problemy administracyjne w konstytucji, Kraków 1936.

Panejko J., Geneza i podstawy samorzadu europejskiego, Paryż 1926.

Rabska T., Pozycja samorzadu terytorialnego w Konstytucji, „Ruch Prawniczy, Ekonomiczny i Socjologiczny" 57, 1995, z. 2.

Chambers of Commerce in Europe. Self-governance and Institutional Change, red. D. Sack, Cham 2021.

Szustek A., Naczelna Izba Gospodarcza, Warszawa 2017.

Szydło M., Samorzad gospodarczy w warunkach gospodarki rynkowej, „Państwo i Prawo” 2005, z. 3 .

Szydło M., Komentarz do art. 17, [w:] Konstytucja RP. T. 1, Komentarz, red. M. Safjan, L. Bosek, Warszawa 2016.

Tabernacka M., Samorzad nieterytorialny, [w:] Tadeusz Bigo o administracji i prawie administracyjnym — refleksje wrocławskiej szkoły administratywistycznej, red. T. Kocowski, P. Lisowski, M. Paplicki, Wrocław 2020.

Vambery R.G., Mayer P., From Government Focus to Customer Focus: The Challenge Facing Chamber of Commerce in Central and Eastern Europe, ,Journal of Global Business and Technology" 1, 2005, nr 2.

Walkowiak K., Samorząd gospodarczy jako partner samorzadu terytorialnego w rozwoju gospodarki lokalnej i regionalnej, „Problemy Zarządzania, Finansów i Marketingu” 2014, nr 35.

Waters S., Chambers of Commerce and Local Development in France: Problems and Constraints, „Environment and Planning C: Government and Policy” 16, 1998, z. 5.

Wykrętowicz S., Funkcjonowanie samorzadu gospodarczego w wybranych krajach europejskich, Warszawa 2013.

Wykrętowicz S., Powstanie i rozwój samorządu gospodarczego w Europie i w Polsce, [w:] Spór o samorząd gospodarczy, red. S. Wykrętowicz, Poznań 2005.

Zdebski A., Samorzad gospodarczy istotnym partnerem administracji rządowej w zarządzaniu państwem w Polsce, http://www.riph.com.pl/download/plikiNews/pliki/000499-IMG_0003.pdf.

Zimmermann J., Prawo administracyjne, Warszawa 2014.

Prawo 333, 2021

(C) for this edition by CNS 


\title{
Institution of the Economic Self-Government in the Polish Law in the Light of the Solutions Adopted in the European Countries
}

\begin{abstract}
Summary
As the result of complex historical events, two models of economic self-government were developed in the second half of the 19th century in Europe and Great Britain, i.e. the continental model and the Anglo-Saxon model. In Poland after 1918, the debate occurred about the model of economic self-government. Legislation on economic self-government which is now in force does not allow to recognize it as a part of public administration and is different from the one from the inter-war period. The present paper examines the institution of economic self-government in the Polish law in the light of the solutions adopted in European countries. It also analyses Polish legal solutions from the inter-war period.
\end{abstract}

Keywords: non-territorial self-government, economic self-government, chambers of commerce, public law association. 